\title{
Short communication: The influence of solids concentration and bleaching agent on bleaching efficacy and flavor of sweet whey powder
}

\author{
M. G. Jervis, T. J. Smith, and M. A. Drake ${ }^{1}$ \\ Department of Food, Bioprocessing and Nutrition Sciences, Southeast Dairy Foods Research Center, North Carolina State University, \\ Raleigh 27695
}

\begin{abstract}
Recent studies have demonstrated the effect of bleaching conditions and bleaching agent on flavor and functional properties of whey protein ingredients. Solids concentration at bleaching significantly affected bleaching efficacy and flavor effects of different bleaching agents. It is not known if these parameters influence quality of sweet whey powder (SWP). The purpose of this study was to determine the effects of solids concentration and bleaching agent on the flavor and bleaching efficacy of SWP. Colored cheddar whey was manufactured, fat separated, and pasteurized. Subsequently, the whey ( $6.7 \%$ solids) was bleached, concentrated using reverse osmosis (RO) to $14 \%$ solids, and then spray dried, or whey was concentrated before bleaching and then spray dried. Bleaching treatments included a control (no bleaching, $50^{\circ} \mathrm{C}, 60 \mathrm{~min}$ ), hydrogen peroxide (HP; $\left.250 \mathrm{mg} / \mathrm{kg}, 50^{\circ} \mathrm{C}, 60 \mathrm{~min}\right)$, benzoyl peroxide $(50 \mathrm{mg} /$ $\left.\mathrm{kg}, 50^{\circ} \mathrm{C}, 60 \mathrm{~min}\right)$, lactoperoxidase $(20 \mathrm{mg} / \mathrm{kg}$ of $\mathrm{HP}$, $50^{\circ} \mathrm{C}, 30 \mathrm{~min}$ ), and external peroxidase (MaxiBright, DSM Food Specialties, Delft, the Netherlands; 2 dairy bleaching units $/ \mathrm{mL}, 50^{\circ} \mathrm{C}, 30 \mathrm{~min}$ ). The experiment was repeated in triplicate. Sensory properties and volatile compounds of SWP were evaluated by a trained panel and gas chromatography-mass spectrometry, respectively. Bleaching efficacy (norbixin destruction) and benzoic acid were measured by HPLC. Differences in bleaching efficacy, sensory and volatile compound profiles, and benzoic acid were observed with different bleaching agents, consistent with previous studies. Solids concentration affected bleaching efficacy of HP, but not other bleaching agents. The SWP from whey bleached with $\mathrm{HP}$ or lactoperoxidase following RO had increased cardboard and fatty flavors and higher concentrations of lipid oxidation compounds compared with SWP from whey bleached before RO. The SWP bleached with benzoyl peroxide after RO contained
\end{abstract}

Received August 31, 2014.

Accepted December 17, 2014.

${ }^{1}$ Corresponding author: mdrake@ncsu.edu less benzoic acid than SWP from whey bleached before $\mathrm{RO}$. These results indicate that solids concentration at bleaching and bleaching agent affect quality of SWP.

Key words: sweet whey, reverse osmosis, bleaching

\section{Short Communication}

Cheddar cheese is colored using the carotenoid annatto, which is primarily composed of norbixin (Smith et al., 2014). Of the added annatto, a portion of the norbixin $(\sim 10 \%)$ remains in the liquid sweet whey, imparting a yellow color (Smith et al., 2014). Dried whey ingredients that are both colorless and flavorless are desired to avoid unwanted color and flavor transfer to final food products. To obtain a colorless product, bleaching is a required step in whey ingredient manufacture. Bleaching parameters in whey production vary among manufacturers, but can occur at any point in the manufacturing process. Processing steps in manufacture of whey protein concentrate (WPC) with $34 \%$ protein (WPC34), WPC80, and whey protein isolate (WPI), including bleaching, impart off-flavors, which carry over to food or beverage applications (Croissant et al., 2009; Campbell et al., 2012; Listiyani et al., 2011; Jervis et al., 2012); thus, care should be taken to maximize final product quality.

Benzoyl peroxide (BP) and hydrogen peroxide (HP) are the 2 approved chemical bleaching agents used in the United States for bleaching of liquid whey and whey retentate. The use of BP for bleaching has declined in recent years due to concerns of some countries regarding benzoic acid residues, but remains an approved chemical bleaching agent, and chemical bleaching with $\mathrm{HP}$ or BP remain cost effective methods for bleaching. However, the nonspecific oxidation processes that reduce norbixin increase lipid oxidation products, which are the primary source of off-flavors in dried whey protein products (Whitson et al., 2010). Bleaching liquid whey or concentrated whey with HP produces higher levels of lipid oxidation and subsequent off flavors than BP (Croissant et al., 2009; Listiyani et al., 2011; Jervis et al., 2012; Fox et al., 2013). At optimal conditions in fluid whey, BP is a better bleaching agent than HP. In 
contrast, in $80 \%$ protein liquid retentate, HP destroyed more norbixin than BP (Fox et al., 2013). Li et al. (2012) examined the effects of bleaching at varying solids levels with $\mathrm{HP}$ at $250 \mathrm{mg} / \mathrm{kg}$ and reported bleaching $80 \%$ whey protein retentate produced greater bleaching efficacy than $34 \%$ whey protein retentate at equivalent solids, indicating that solids composition directly affected bleaching efficacy of HP.

Concerns over chemical bleaching agents have led to research into alternative bleaching methods. Enzymatic bleaching with the lactoperoxidase system (LP) is one alternative bleaching method (Bottomley et al., 1989; Campbell et al., 2012). Bleaching fluid whey with LP $(20 \mathrm{mg} / \mathrm{kg}$ of $\mathrm{HP})$ was more effective in norbixin destruction than chemical bleaching with HP $(250 \mathrm{mg} / \mathrm{kg}$ of HP; LP >99\% norbixin destruction at both 50 and $35^{\circ} \mathrm{C}$ vs. $\mathrm{HP} 46 \%$ at $50^{\circ} \mathrm{C}$ or $32 \%$ at $35^{\circ} \mathrm{C}$; Campbell et al., 2012). The use of an external peroxidase (EP) has recently been approved by the Food and Drug Administration as an additional enzymatic bleaching agent for whey. External peroxidase facilitates enzymatic bleaching of whey similar to the LP system, but can account for variability in lactoperoxidase levels that may result from varying feeding regimens and processing steps (Seifu and Donkin, 2005; Campbell and Drake, 2014). In the case of LP, bleaching at higher protein concentration may facilitate bleaching by increasing concentrations of LP, as LP is concentrated by UF with other proteins. Higher solids in general may also facilitate bleaching with other agents simply due to a concentration effect: generated radicals have more ready access to available norbixin. However, previous studies have also suggested that bleaching at higher solids may also lead to higher concurrent concentrations of lipid oxidation compounds (Fox et al., 2013). The effect of bleaching fluid whey at various solids concentration levels is not yet fully understood in regards to the potential effect on both bleaching efficacy and flavor, and no published studies to our knowledge have evaluated the effect of bleaching on sensory and chemical properties of sweet whey powder (SWP). The objective of the current study was to examine the effect of bleaching of colored liquid whey at 2 concentrations of TS on the sensory and chemical properties of SWP.

\section{Experimental Design}

Liquid pasteurized, fat-separated cheddar whey was divided into 2 batches. The first batch was further divided into 5 sample groups based on bleaching method. These samples included 1 control (CR) and wheys bleached using HP, BP, LP, or EP at the solids of unconcentrated whey (approximately 6.7\%). All 5 of the
Table 1. Descriptions of sweet whey powder (SWP) treatments

\begin{tabular}{ll}
\hline Treatment $^{1}$ & Description \\
\hline CR & Control before RO ${ }^{2}$ \\
CR14 & Control after RO \\
HP & Hydrogen peroxide before RO \\
HP14 & Hydrogen peroxide after RO \\
BP & Benzoyl peroxide before RO \\
BP14 & Benzoyl peroxide after RO \\
LP & Lactoperoxidase before RO \\
LP14 & Lactoperoxidase after RO \\
EP & External peroxidase before RO \\
EP14 & External peroxidase after RO \\
\hline
\end{tabular}

${ }^{1} \mathrm{CR}=$ control (no bleaching), HP = bleaching with hydrogen peroxide (250 mg/kg); BP = bleaching with benzoyl peroxide $(50 \mathrm{mg} / \mathrm{kg}) ; \mathrm{LP}$ = bleaching with lactoperoxidase (hydrogen peroxide $20 \mathrm{mg} / \mathrm{kg}$ ); EP $=$ bleaching with external peroxidase (2 dairy bleaching units and hydrogen peroxide $20 \mathrm{mg} / \mathrm{kg}$ ); CR14, HP14, BP14, LP14, and EP14 $=$ wheys concentrated to $14 \%$ TS using RO and bleached as before. ${ }^{2} \mathrm{RO}=$ reverse osmosis to $14 \%$ solids.

wheys were then concentrated to approximately $14 \%$ TS using reverse osmosis ( $\mathbf{R O}$ ) and spray dried. The second batch was concentrated to $14 \%$ TS and then separated into 5 sample groups (CR14, HP14, BP14, LP14, and EP14). These sample groups were then bleached at the higher TS concentration using the same 5 bleaching methods. Following bleaching and concentration, all sweet whey samples were cooled to $4^{\circ} \mathrm{C}$ and stored overnight. The following day, all samples were spray dried (Table 1); this experiment was replicated 3 times.

\section{Sweet Whey Manufacture, Bleaching, and Concentration}

Cheddar whey was manufactured from HTST (17 $\mathrm{s}$ at $72^{\circ} \mathrm{C}$ ) pasteurized whole milk (approximately $1,400 \mathrm{~kg}$ ), fat separated, and pasteurized following the methods of Campbell and Drake (2013). Fluid whey was then cooled to $50^{\circ} \mathrm{C}$ and divided into 2 batches weighing approximately 625 and $125 \mathrm{~kg}$, respectively. Batch $1(625 \mathrm{~kg})$ was separated into 5 aliquots for bleaching, each approximately $125 \mathrm{~kg}$. These 5 aliquots were bleached at TS concentrations of fluid whey (6.7\% solids). All bleaching took place at $50^{\circ} \mathrm{C}$ (Fox et al., 2013). The HP (35\% HP, Food Chemicals Codex grade; Columbus Chemical Industries Inc., Columbus WI) was added at $250 \mathrm{mg} / \mathrm{kg}$ to 1 aliquot and held for $60 \mathrm{~min}$. This concentration was selected because it represents the midrange concentration of HP use for bleaching of whey (US Food and Drug Administration, 2009). The BP (Oxylite Type XX Benzoyl Peroxide $32 \%$, Nelson Jameson, Marshfield, WI) was added to the second aliquot at a concentration of $50 \mathrm{mg} / \mathrm{kg}$ and 
held for $60 \mathrm{~min}$. This concentration represents a moderate concentration that is within the range covered by good manufacturing procedures. The LP system was activated in the third aliquot by addition of $20 \mathrm{mg} / \mathrm{kg}$ of HP and held for $30 \mathrm{~min}$ (Campbell et al., 2012). The fourth aliquot was bleached with the addition of EP (MaxiBright, DSM Food Specialties, Delft, the Netherlands) at a concentration of 2 dairy bleaching units and $20 \mathrm{mg} / \mathrm{kg}$ of HP for $30 \mathrm{~min}$ (Campbell et al., 2012; Campbell and Drake, 2013). Both EP and LP samples were held at $50^{\circ} \mathrm{C}$ for 30 min before bleaching to ensure that total heat exposure was consistent with other samples. A fifth aliquot was held at $50^{\circ} \mathrm{C}$ for $60 \mathrm{~min}$, but remained unbleached (control). Catalase (FoodPro CAT, Danisco, New Century, NJ) was added at a rate of $20 \mathrm{mg} / \mathrm{kg}$ to remove any remaining $\mathrm{HP}$ and to stop LP and EP activity. These aliquots were cooled to $4^{\circ} \mathrm{C}$ and held until concentrated using RO and spray dried the next day.

Batch 2 of liquid whey $(125 \mathrm{~kg})$ was concentrated to approximately 14\% TS concentration immediately following pasteurization and cooled without bleaching. Whey was transferred to a holding tank and pumped using a centrifugal pump to the RO system at $4^{\circ} \mathrm{C}$. The RO system was equipped with a high-pressure pump (model A96084762P10324US193, Grundfos Pumps Corporation, Olathe, KS) and two 4-in outer diameter reverse osmosis thin-film composite filter column membranes (model RO-SYN2-4040, Snyder Filtration, Vacaville, CA). The system was run at approximately $1,310 \mathrm{kPa}$. The retentate was the partially concentrated whey, which was cycled back into the holding tank to undergo further concentration. Total solids levels were monitored using the Smart System 5 moisture-solids analyzer (CEM, Matthews, NC). Once the desired $14 \%$ TS concentration was reached $(\sim 1 \mathrm{~h})$, the concentrated whey was cooled and held at $4^{\circ} \mathrm{C}$ (batch 1 treatments). The remaining volume of concentrated whey was then divided into 5 equally sized containers (approximately $2 \mathrm{~L}$ each) and bleached using the parameters outlined previously. All samples were spray dried the following day (model Lab 1, Anhydro Inc., Soeberg, Denmark). Inlet temperature was $175^{\circ} \mathrm{C}$ and outlet temperature was $80^{\circ} \mathrm{C}$. Total spray-drying time was $1 \mathrm{~h}$ per sample. Sweet whey powders were stored in mylar bags and held at $-80^{\circ} \mathrm{C}$ until analyses (initiated within $1 \mathrm{wk}$ ).

\section{Composition and Color Analysis}

The SWP powders were analyzed for moisture, fat, protein, and minerals as described by Campbell and Drake (2013). Hunter L* (lightness), a* (red-green), and $b^{*}$ (yellow-blue) values were measured in both dry powders $(10 \mathrm{~g}$ ) and liquids [10 $\mathrm{mL}$ of $10 \%$ (wt/vol) solution; Campbell and Drake, 2013].

\section{Norbixin Extraction and Analysis}

Norbixin was extracted and quantified from liquid wheys to measure the percent norbixin destruction. Extraction of norbixin was conducted and quantified by HPLC using the method described by Campbell et al. (2014; Waters 1525 Binary Pump, Waters, Milford, MA). Norbixin destruction was calculated on a percentage basis by comparison of the peak area and retention time of norbixin in bleached samples with the peak area found in control samples.

\section{Descriptive Sensory Analysis}

The SWP were rehydrated $(10 \% \mathrm{wt} / \mathrm{vol})$ in deionized water and evaluated in duplicate by 8 trained panelists, each with more than $150 \mathrm{~h}$ of experience with descriptive analysis of dried dairy ingredient aroma and flavor, using the Spectrum descriptive analysis method (Meilgaard et al., 2007). Aroma and flavor attributes of reconstituted SWP were evaluated using a 0- to 15-point universal scale and an established lexicon for dried dairy ingredients (Drake, et al., 2003; Wright et al., 2009). Samples were tempered to $20^{\circ} \mathrm{C}$ and evaluated at room temperature by each panelist in duplicate. Sensory data were collected using Compusense 5 (release 5.2; Compusense Inc., Guelph, ON, Canada).

\section{Volatile Compound Analysis}

Selected volatile compounds in liquid whey were extracted by solid-phase microextraction using selective ion monitoring. These compounds were chosen based on prior research and relevance to flavor of whey, bleaching of whey, or both (Campbell et al., 2012; Jervis et al., 2012; Listiyani et al., 2012; Campbell and Drake, 2013). Spray-dried powders were reconstituted at $10 \%$ solids (wt/vol). All samples contained $10 \%$ (wt/vol) sodium chloride (Fisher Scientific, Fairlawn, NJ) and $10 \mu \mathrm{L}$ of internal standard solution (2-methyl-3-heptanone in methanol at 81 ppm; Sigma Aldrich, Milwaukee, WI) in 20-mL autosampler vials with steel screw tops containing silicone septa faced in Teflon (Microliter Analytical, Suwanee, GA) as described by Campbell et al. (2013). These compounds were then separated and identified by GC-MS using the method of Campbell and Drake (2013). Compounds of interest were identified using the National Institutes of Standards and Technology 2005 library of spectra (www.nist.gov) and by comparison of 
spectra of authentic standards injected under identical conditions. Relative abundance for each compound was calculated using the calculated recovery of the internal standard concentration to determine relative concentrations of each compound.

\section{Benzoic Acid Extractions and Measurement}

Residual benzoic acid (BA) was extracted and quantified following a method developed by Listiyani et al. (2011). A standard curve for BA was constructed at concentrations of $0.5,1,3,5,10,25$, and $50 \mathrm{mg} / \mathrm{kg}$. To create this standard, BA (EMD Chemicals, Darmstadt, Germany) was added to mobile phase solutions at the appropriate concentrations and analyzed on the same HPLC system. The extracted samples were injected in duplicate. Additionally, a control sample of unbleached whey was spiked with BA standard $(10 \mathrm{mg} / \mathrm{kg})$, extracted and injected, and used to calculate BA recovery. Benzoic acid concentrations were calculated based on the standard curve, recovery rate, and dilution factors.

\section{Statistical Analysis}

Data were analyzed using 2-way (bleach type $\times$ solids) ANOVA using a general linear model with Fishers least significant difference for means separation (XLSTAT, Version 2013.05.05; Addinsoft Inc., New York, NY). Both main effects and interaction effects were analyzed. Principal component analysis (XLSTAT) was conducted to visualize differences among treatments.

\section{Composition Analysis}

No compositional differences were detected among the SWP $(P>0.05)$. Moisture content was $1.18 \pm$ $0.32 \%$, fat content was $0.65 \pm 0.08 \%$, and protein content was $12.7 \pm 0.2 \%$ (Mavropoulou and Kosikowski 1972; Sithole et al., 2005). Similarly, no differences were detected in mineral concentrations $(P>0.05)$ except for iron content, which was lower $(P<0.05)$ when whey was bleached with HP at $14 \%$ solids when compared with SWP from whey bleached with HP at $6.7 \%$ solids ( 2.34 vs. $2.04 \mathrm{mg} / \mathrm{kg}, P<0.05)$. Mineral values were also consistent with previous studies (Sithole et al., 2005). Lower iron content has been previously reported in WPC80 from fluid whey bleached with HP at a higher temperature $\left(66^{\circ} \mathrm{C}\right)$ and higher concentration $(500 \mathrm{mg} / \mathrm{kg}$; Jervis et al., 2012). Jervis and Drake (2013) hypothesized that this decrease in iron was due to Fenton reactions, which might result in the release of protein-bound iron.

\section{Color Analysis and Norbixin Extraction and Analysis}

Significant differences in Hunter $\mathrm{L}^{*}, \mathrm{a}^{*}, \mathrm{~b}^{*}$ values $(P<0.05)$ were observed in both SWP and in rehydrated SWP (10\% wt/vol; Table 2). In both SWP and rehydrated SWP (10\% wt/vol), BP and BP14 had significantly lower $\mathrm{b}^{*}$ values, indicating decreased yellow color compared with control and other bleaching treatments (Table 2). All bleaching treatments, regardless of the point in the process at which bleaching occurred, were significantly lower in $b^{*}$ compared with control

Table 2. Mean color [L* (lightness), a* (red-green), and b* (yellow-blue) values] of spray-dried rehydrated sweet whey powder (SWP) bleached before or after reverse osmosis (14\% solids)

\begin{tabular}{|c|c|c|c|c|c|c|}
\hline \multirow[b]{2}{*}{ Treatment $^{1}$} & \multicolumn{3}{|c|}{ Powder } & \multicolumn{3}{|c|}{$\begin{array}{l}\text { Liquid } \\
(10 \% \text { rehydrated wt/vol) }\end{array}$} \\
\hline & $\mathrm{L}^{*}$ & $a^{*}$ & $b^{*}$ & $\mathrm{~L}^{*}$ & $a^{*}$ & $b^{*}$ \\
\hline CR & $95.1^{\mathrm{d}}$ & $-0.9^{\mathrm{a}}$ & $10.8^{\mathrm{a}}$ & $75.2^{\mathrm{c}}$ & $-1.8^{\mathrm{a}}$ & $12.8^{\mathrm{a}}$ \\
\hline CR14 & $95.1^{\mathrm{d}}$ & $-1.1^{\mathrm{a}}$ & $10.9^{\mathrm{a}}$ & $75.3^{\mathrm{c}}$ & $-1.7^{\mathrm{a}}$ & $12.9^{\mathrm{a}}$ \\
\hline $\mathrm{BP}$ & $96.3^{\mathrm{a}}$ & $-2.3^{\mathrm{b}}$ & $7.6^{\mathrm{c}}$ & $77.8^{\mathrm{a}}$ & $-2.3^{\mathrm{a}}$ & $8.4^{\mathrm{d}}$ \\
\hline BP14 & $96.4^{\mathrm{a}}$ & $-2.5^{\mathrm{b}}$ & $7.4^{\mathrm{c}}$ & $77.7^{\mathrm{a}}$ & $-2.3^{\mathrm{a}}$ & $8.6^{\mathrm{d}}$ \\
\hline HP & $95.4^{\mathrm{bcd}}$ & $-1.9^{\mathrm{b}}$ & $10.0^{\mathrm{ab}}$ & $76.3^{\mathrm{b}}$ & $-1.9^{\mathrm{a}}$ & $11.0^{\mathrm{ab}}$ \\
\hline HP14 & $95.3^{\mathrm{cd}}$ & $-1.9^{\mathrm{b}}$ & $9.1^{\mathrm{b}}$ & $76.4^{\mathrm{b}}$ & $-1.8^{\mathrm{a}}$ & $10.1^{\mathrm{bc}}$ \\
\hline LP & $95.8^{\mathrm{bc}}$ & $-2.2^{\mathrm{b}}$ & $9.4^{\mathrm{b}}$ & $77.2^{\mathrm{ab}}$ & $-2.2^{\mathrm{a}}$ & $9.4^{\mathrm{cd}}$ \\
\hline LP14 & $95.3^{\text {cd }}$ & $-2.1^{\mathrm{b}}$ & $9.0^{\mathrm{b}}$ & $76.1^{\mathrm{b}}$ & $-2.1^{\mathrm{a}}$ & $10.0^{\mathrm{bc}}$ \\
\hline $\mathrm{EP}$ & $95.6^{\mathrm{bc}}$ & $-2.3^{\mathrm{b}}$ & $9.3^{\mathrm{b}}$ & $77.1^{\mathrm{b}}$ & $-2.3^{\mathrm{a}}$ & $9.3^{\mathrm{cd}}$ \\
\hline EP14 & $95.3^{\mathrm{cd}}$ & $-2.2^{\mathrm{b}}$ & $9.1^{\mathrm{b}}$ & $76.5^{\mathrm{b}}$ & $-2.2^{\mathrm{b}}$ & $10.1^{\mathrm{bc}}$ \\
\hline
\end{tabular}


with the exception of HP, which was not different from control $(P>0.05)$. Previous work has also reported higher yellowness in WPC80 and SPC80 from colored and uncolored whey bleached with HP compared with BP (Jervis et al., 2012; Campbell et al., 2013).

An interaction between point at which bleaching was applied (6.7 vs. $14 \%$ TS concentration) and bleaching agent was observed for norbixin destruction $(P<0.05)$. Percent norbixin destruction was not different with point at which bleaching was applied for BP, LP, or EP $(P>0.05$; Figure 1). In contrast, HP bleaching before $\mathrm{RO}$ resulted in lower norbixin destruction than bleaching with HP at higher solids (HP14; $P<0.05$ ). These results are consistent with results reported by Fox et al. (2013), who found that HP $(250 \mathrm{mg} / \mathrm{kg}$ ) bleaching of liquid whey $(6.7 \% \mathrm{TS})$ at $50^{\circ} \mathrm{C}$ destroyed less norbixin than bleaching with the same parameters of liquid whey retentate [12\% TS; $80 \%$ protein (wt/wt)] manufactured by UF. Li et al. (2012) reported increased bleaching efficacy $(P<0.05)$ with HP $(250 \mathrm{mg} / \mathrm{kg})$ when bleaching liquid WPC80 or liquid WPC34 than fluid whey, confirming the role of composition on HP bleaching. Fox et al. (2013) hypothesized that increased HP bleaching efficiency at higher solids was due to a combination of chemical HP bleaching as well as some bleaching with concentrated native LP. The native LP is permanently oxidized by the excess HP (Bottomley at al., 1989), but sufficient concentrations are present at higher solids to result in some bleaching before inactivation. The current study indicates that concentration of solids also increases HP bleaching efficacy.

\section{Descriptive Sensory Analysis}

Sensory profiles of rehydrated SWP (10\% wt/vol) bleached before and after RO were distinct (Table 3). The point at which bleaching was applied had no effect on the sensory profiles of BP and EP; however, the point at which bleaching was applied did affect the flavor profiles of HP and LP $(P<0.05)$. The SWP from HP14 was higher in cardboard flavor, whereas SWP from LP14 was significantly higher in cardboard and fatty flavors, which are both off flavors associated with lipid oxidation products (Whitson et al., 2010).

\section{Volatile Compound Analysis}

The point at which bleaching was applied had a significant effect on lipid oxidation and protein degradation compounds (Figure 2). Bleaching after RO increased

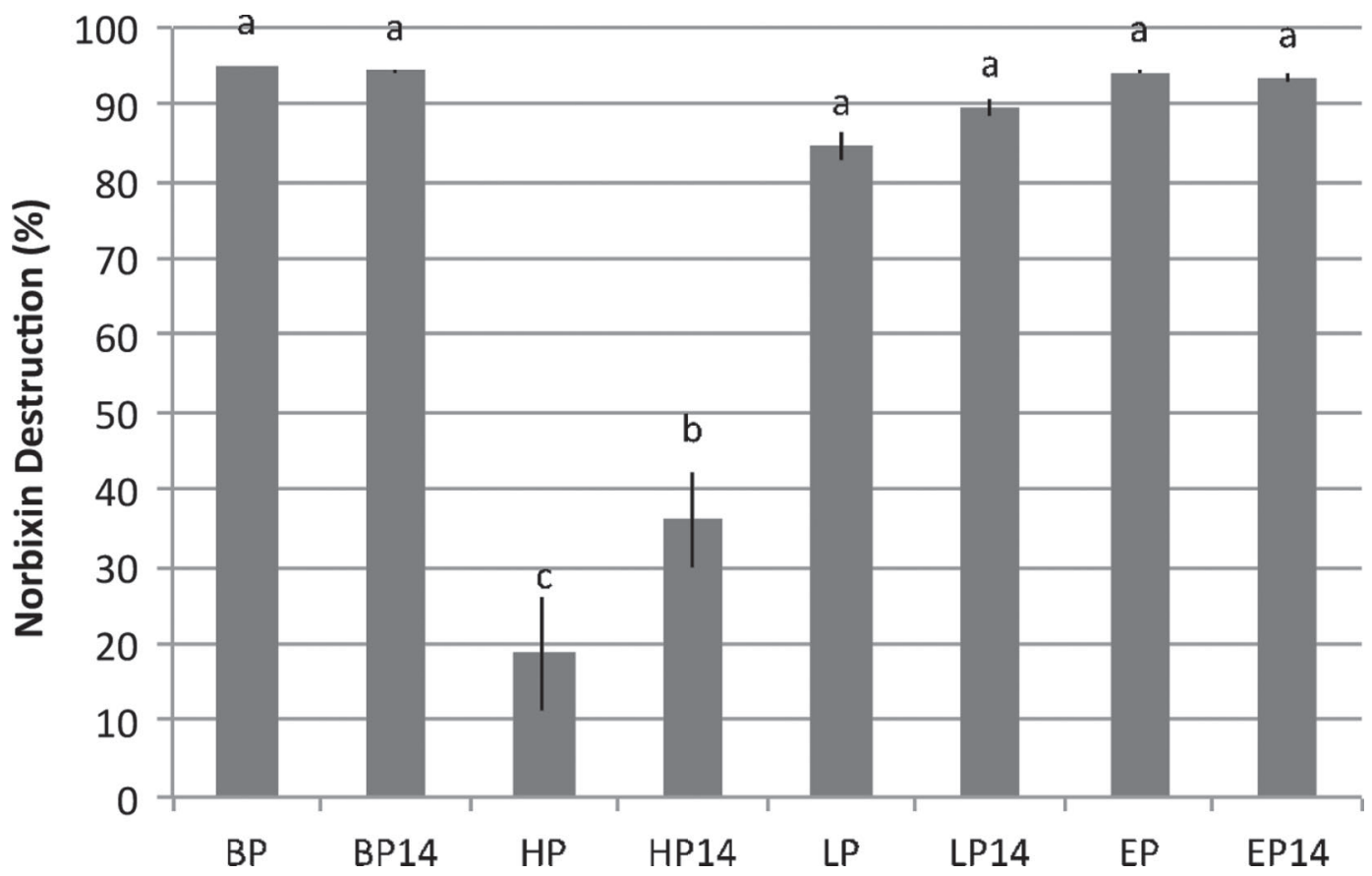

Figure 1. Mean $( \pm \mathrm{SD})$ percent norbixin destruction of sweet whey powders $(\mathrm{SWP})$ from whey bleached before or after reverse osmosis $(14 \%$ solids). Different letters indicate significant differences $(P<0.05)$. HP $=$ bleaching with hydrogen peroxide $(250 \mathrm{mg} / \mathrm{kg}) ; \mathrm{BP}=\mathrm{bleaching}$ with benzoyl peroxide $(50 \mathrm{mg} / \mathrm{kg}) ; \mathrm{LP}=$ bleaching with lactoperoxidase (hydrogen peroxide $20 \mathrm{mg} / \mathrm{kg}$ ); EP = bleaching with external peroxidase (2 dairy bleaching units and hydrogen peroxide $20 \mathrm{mg} / \mathrm{kg}$ ); HP14, BP14, LP14, and EP14 = wheys concentrated to $14 \%$ TS using RO and bleached as before. 
Table 3. Mean sensory profiles of sweet whey powders (SWP) bleached before or after reverse osmosis $(14 \% \text { solids })^{1}$

\begin{tabular}{|c|c|c|c|c|c|c|c|c|}
\hline Treatment $^{2}$ & $\begin{array}{l}\text { Aroma } \\
\text { intensity }\end{array}$ & $\begin{array}{c}\text { Sweet } \\
\text { aromatic }\end{array}$ & Buttery & $\begin{array}{l}\text { Chlorine/ } \\
\text { chemical }\end{array}$ & Cardboard & Fatty & $\begin{array}{l}\text { Sweet } \\
\text { taste }\end{array}$ & $\begin{array}{l}\text { Salty } \\
\text { taste }\end{array}$ \\
\hline CR & $2.3^{\mathrm{a}}$ & $1.9^{\mathrm{a}}$ & 0.5 & $\mathrm{ND}^{3}$ & $1.1^{\mathrm{d}}$ & ND & 2.5 & 1.5 \\
\hline CR14 & $2.2^{\mathrm{a}}$ & $1.8^{\mathrm{a}}$ & 0.5 & ND & $1.0^{\mathrm{d}}$ & ND & 2.6 & 1.5 \\
\hline BP14 & $2.0^{\mathrm{bc}}$ & $1.2^{\mathrm{b}}$ & ND & 0.6 & $1.6^{\mathrm{c}}$ & ND & 2.5 & 1.7 \\
\hline HP & $1.6^{\mathrm{d}}$ & $0.7^{\mathrm{c}}$ & ND & ND & $2.2^{\mathrm{b}}$ & 0.5 & 2.4 & 1.6 \\
\hline HP14 & $1.9^{\mathrm{bcd}}$ & $0.5^{\mathrm{c}}$ & ND & ND & $2.8^{\mathrm{a}}$ & 0.8 & 2.0 & 1.4 \\
\hline EP14 & $1.9^{\mathrm{bcd}}$ & $1.1^{\mathrm{b}}$ & ND & ND & $2.3^{\mathrm{b}}$ & ND & 2.5 & 1.6 \\
\hline
\end{tabular}

${ }^{\mathrm{a}-\mathrm{d}}$ Means in a column followed by a different letter are significantly different $(P<0.05)$.

${ }^{1}$ Attributes were evaluated using a 0 - to 15 -point universal intensity scale. Most dried ingredient flavors fall between 0 and 4 on this scale. ${ }^{2} \mathrm{CR}=$ control (no bleaching), $\mathrm{HP}=$ bleaching with hydrogen peroxide $(250 \mathrm{mg} / \mathrm{kg}) ; \mathrm{BP}=$ bleaching with benzoyl peroxide $(50 \mathrm{mg} / \mathrm{kg}) ; \mathrm{LP}=$ bleaching with lactoperoxidase (hydrogen peroxide $20 \mathrm{mg} / \mathrm{kg}$ ); $\mathrm{EP}=$ bleaching with external peroxidase (2 dairy bleaching units and hydrogen peroxide $20 \mathrm{mg} / \mathrm{kg}$ ); CR14, HP14, BP14, LP14, and EP14 = wheys concentrated to $14 \% \mathrm{TS}$ using RO and bleached as before.

${ }^{3} \mathrm{ND}=$ not detected.

volatile formation for SWP from HP, BP, LP, and EP $(P<0.05)$, although not in a consistent manner. In HP-, LP-, and EP-bleached SWP, higher levels of lipid oxidation and protein degradation compounds, including dimethyl sulfide, hexanal, heptanal, and octanal, were found when bleached at $14 \%$ when compared

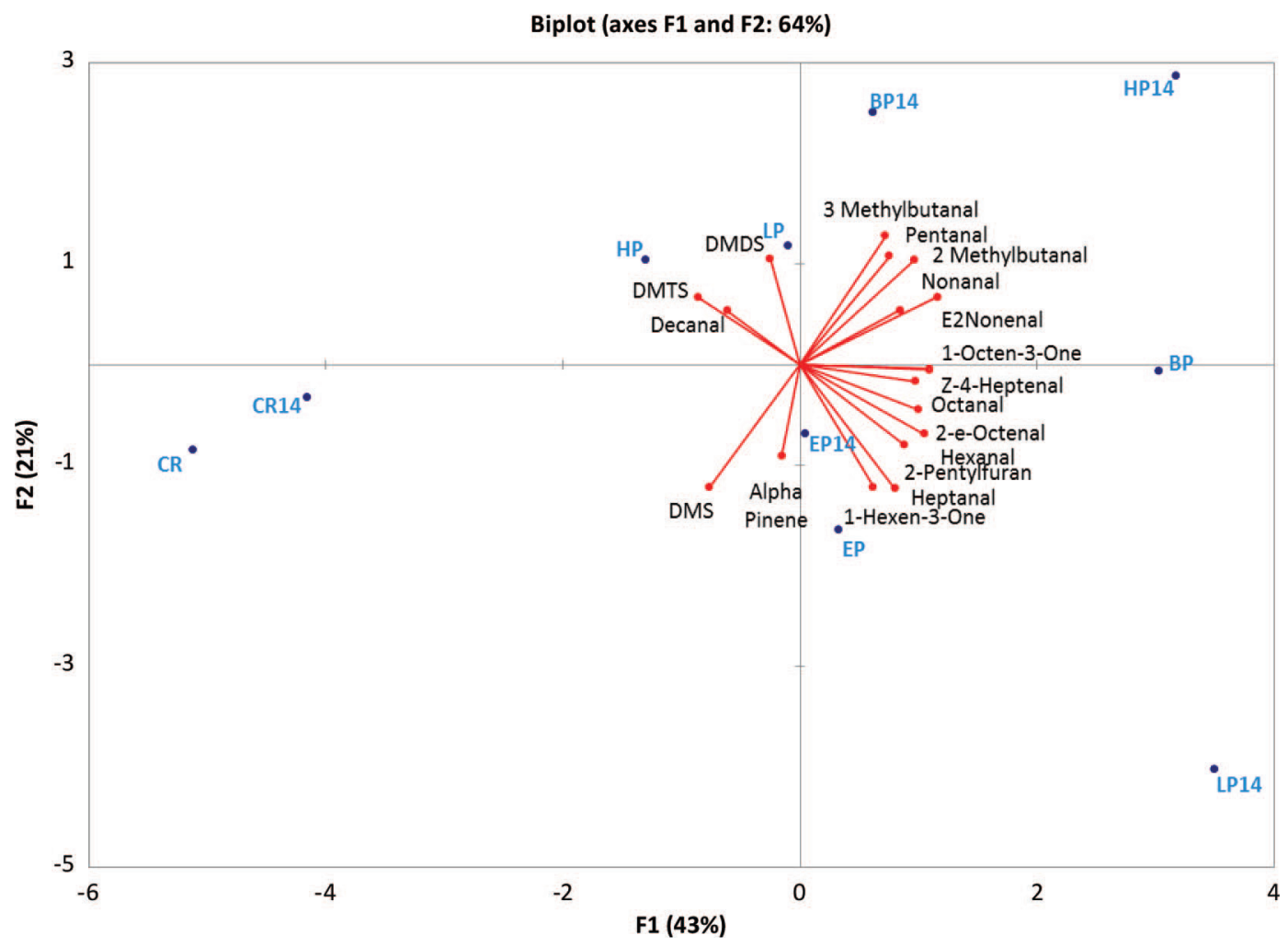

Figure 2. Principal component (PC) biplot (showing factors 1 and 2, F1 and F2) of volatile compound analysis (GC-MS) of sweet whey powders (SWP) bleached before or after reverse osmosis (14\% solids). CR = control (no bleaching), HP = bleaching with hydrogen peroxide $(250 \mathrm{mg} / \mathrm{kg}) ; \mathrm{BP}=$ bleaching with benzoyl peroxide $(50 \mathrm{mg} / \mathrm{kg}) ; \mathrm{LP}=$ bleaching with lactoperoxidase (hydrogen peroxide $20 \mathrm{mg} / \mathrm{kg}) ; \mathrm{EP}=$ bleaching with external peroxidase (2 dairy bleaching units and hydrogen peroxide $20 \mathrm{mg} / \mathrm{kg}$ ); CR14, HP14, BP14, LP14, and EP14 = wheys concentrated to $14 \%$ TS using RO and bleached as before. DMTS = dimethyl trisulfide; DMDS = dimethyl disulfide; DMS $=$ dimethyl sulfide. Color version available online. 


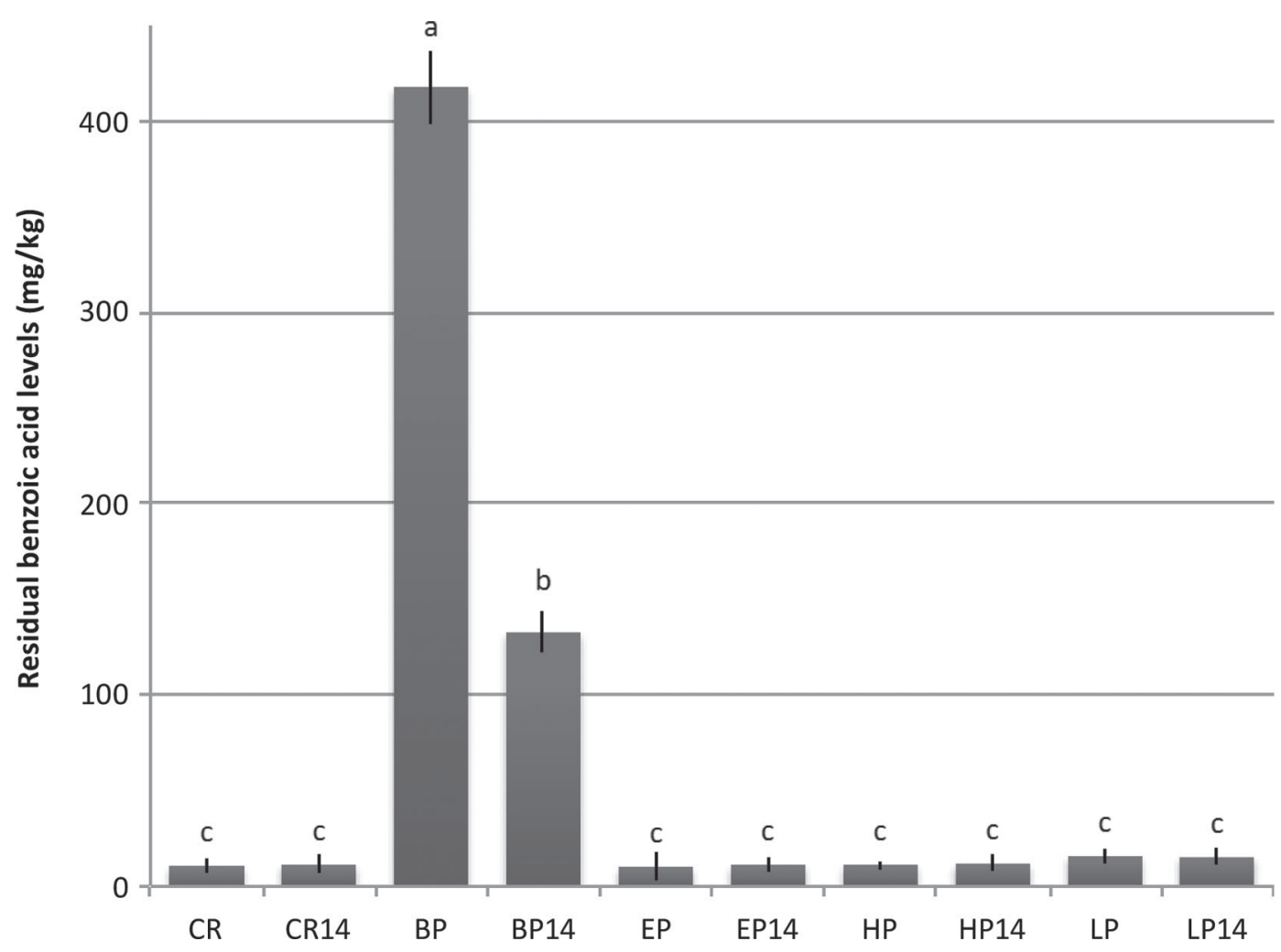

Figure 3. Residual benzoic acid ( $\mathrm{mg} / \mathrm{kg}$; mean $\pm \mathrm{SD}$ ) of sweet whey powders (SWP) bleached before or after reverse osmosis (14\% solids). Different letters $(\mathrm{a}-\mathrm{c})$ indicate significant differences $(P<0.05)$. $\mathrm{CR}=$ control (no bleaching), $\mathrm{HP}=$ bleaching with hydrogen peroxide $(250 \mathrm{mg} /$ $\mathrm{kg}) ; \mathrm{BP}=$ bleaching with benzoyl peroxide $(50 \mathrm{mg} / \mathrm{kg}) ; \mathrm{LP}=$ bleaching with lactoperoxidase (hydrogen peroxide $20 \mathrm{mg} / \mathrm{kg}) ; \mathrm{EP}=\mathrm{bleaching}$ with external peroxidase (2 dairy bleaching units and hydrogen peroxide $20 \mathrm{mg} / \mathrm{kg}$ ); CR14, HP14, BP14, LP14, and EP14 = wheys concentrated to $14 \%$ TS using RO and bleached as before.

with SWP from bleaching at $6.7 \%$ solids $(P<0.05)$. Unbleached SWP contained lower relative abundances of most volatiles than the bleached SWP. Campbell and Drake (2013) also reported higher concentrations of hexanal and other lipid oxidation compounds from WPC80 bleached with HP (250 mg/kg), LP (20 mg/ $\mathrm{kg}$ of HP), and EP (2 dairy bleaching units) compared with unbleached WPC80. Fox et al. (2013) noted that fluid whey retentates were higher in aldehydes than fluid whey, regardless of bleach treatment. Listiyani et al. (2011) and Croissant et al. (2009) also examined the effect of bleaching with HP and BP and reported that BP produced lower levels of lipid oxidation products (aldehydes, ketones, and so on). The point at which bleaching was applied affected BP treatments in that bleaching at 14\% TS resulted in a decrease in hexanal, heptanal, 2-pentylfuran, and 2-E-octenal, and an increase in dimethyl sulfide, dimethyl disulfide, and decanal when compared with treatments bleached at $6.7 \%$ TS $(P<0.05)$. The effect of both increases and decreases in select compounds was only observed with BP.
The SWP from HP14 was higher $(P<0.05)$ in lipid oxidation and protein degradation compounds compared with HP SWP (Figure 2). The SWP from HP14 also had a lower iron concentration compared with HP. Jervis and Drake (2013) hypothesized that iron facilitated the formation of hydroxyl radicals from HP, which then facilitated bleaching and other reactions, such as lipid oxidation and protein degradation. Reverse osmosis will concentrate all minerals present in whey, including iron. The increased concentration of iron when HP was introduced (HP14) may have resulted in increased iron facilitated HP mechanisms, as outlined in Jervis and Drake (2013), which would account for the higher lipid oxidation and protein degradation compounds, as well as the lower iron content in the HP14 treatment.

\section{BA Extractions and Measurement}

Levels of BA in unbleached SWP and SWP bleached with agents other than $\mathrm{BP}$ were consistent with previous studies (Listiyani et al., 2011; Figure 3). The SWP bleached with BP at $14 \%$ TS had lower residual BA 
compared with SWP from whey bleached with BP at $6.7 \%$ TS $(P<0.05$; Figure 3$)$. In both cases, whey was dosed with $50 \mathrm{mg} / \mathrm{kg}$ of BP based on the total weight of the sample. Consistent differences in BA recovery compared with theoretical expected recovery were also noted between BP and BP14. The BA recovery from SWP from whey bleached at native solids was $60 \%$, consistent with previous studies from fluid whey bleached with BP (Listiyani et al., 2011). In contrast, BA recovery from SWP from whey bleached at $14 \%$ solids was $38 \%$. Little published research has addressed the effect of various BP bleaching conditions (concentration, point at which bleaching was applied) on residual BA in spray-dried whey ingredients. Previously, Listiyani et al. (2011) noted that residual BA was lower in BP-bleached WPC34 compared with WPC80, and they then demonstrated that BA was recovered in permeate, demonstrating that some BA was lost during UF and subsequent diafiltration. However, those processes were not present in SWP manufacture in the current study and solids concentration differences do not fully account for the consistent differences in residual BA between SWP from BP bleached fluid whey compared with that from $\mathrm{BP}$ bleached higher solids RO retentate or in the differences in percent theoretical recovery. It is possible that BA becomes bound to protein or solubilized in fat during the bleaching process. Benzoic acid binding to milk protein has been reported (Moriguchi et al., 1968; Wedzicha and Ahmed, 1993). Liquid whey bleached at $14 \%$ solids contained a higher concentration of protein to fat to BP than whey bleached at $6.7 \%$ solids. If BA interacted with or bound to protein or fat, this increased ratio might account for an increased level of BA binding and a decreased BA recovery. Additional studies would be necessary to further clarify this issue with BA recovery evaluated throughout whey processing. Regardless, the current study demonstrates that for SWP manufacture (no UF or diafiltration), bleaching at higher solids concentration decreases residual BA while maintaining comparable BP bleaching efficacy.

\section{Conclusions}

The point at which bleaching was applied significantly affected the bleaching efficacy and resulting flavor of sweet whey powder. Bleaching after RO to $14 \%$ solids increased the bleaching efficacy of HP and negatively affected off-flavor formation from HP and LP. The point at which bleaching was applied also significantly affected residual BA levels in SWP. When bleached after RO, final SWP had a reduced level of BA. Increased solids by RO or evaporation potentially benefit the dairy industry in the processing of SWP by lowering costs associated with processing and spray drying; however, if the whey is to be bleached, it is better to bleach before solids concentration to avoid increased off-flavor production. If bleaching with BP is to be used, bleaching after RO will result in less BA residue.

\section{ACKNOWLEDGMENTS}

Funding provided in part by the Dairy Research Institute [DRI; formerly Dairy Management Inc. (DMI); Rosemont, IL] and by DSM (Delft, the Netherlands). The use of trade names does not imply endorsement nor lack of endorsement by those not mentioned.

\section{REFERENCES}

Bottomley, R. C., R. D. Colvin, and M. Van Blanton, inventors. 1989. Decolorising of whey and whey products derived from whey. Express Foods Group Limited (Middlesex, GB2), assignee. US Pat. No. $4,888,184$.

Campbell, R. E., M. C. Adams, M. A. Drake, and D. M. Barbano. 2013. Effect of bleaching permeate from microfiltered skim milk on $80 \%$ serum protein concentrate. J. Dairy Sci. 96:1387-1400.

Campbell, R. E., I. A. L. A. Boogers, and M. A. Drake. 2014. Short communication: Development of a novel method for the extraction of norbixin from whey and its subsequent quantification via high performance liquid chromatography. J. Dairy Sci. 97:1313-1318.

Campbell, R. E., and M. A. Drake. 2013. Cold enzymatic bleaching of fluid whey. J. Dairy Sci. 96:7404-7413.

Campbell, R. E., and M. A. Drake. 2014. Enzymatic bleaching in commercial colored Cheddar whey retentates. Int. Dairy J. 38:148153.

Campbell, R. E., E. J. Kang, E. Bastian, and M. A. Drake. 2012. The use of lactoperoxidase for the bleaching of fluid whey. J. Dairy Sci. 95:2882-2890.

Croissant, A. E., E. J. Kang, R. E. Campbell, E. Bastian, and M. A. Drake. 2009. The effect of bleaching agent of the flavor of liquid whey and whey protein concentrate. J. Dairy Sci. 92:5917-5927.

Drake, M. A., Y. Karagul-Yuceer, K. R. Cadwallader, G. V. Civille, and P. S. Tong. 2003. Determination of the sensory attributes of dried milk powders and dairy ingredients. J. Sens. Stud. 18:199 216.

Fox, A. J., T. J. Smith, P. D. Gerard, and M. A. Drake. 2013. The influence of bleaching agent and temperatures on bleaching efficacy and volatile components of fluid whey and whey retentate. J. Food Sci. 78:C1535-C1542.

Jervis, S., R. Campbell, K. L. Wojciechowski, E. A. Foegeding, M. A. Drake, and D. M. Barbano. 2012. Effect of bleaching whey on sensory and functional properties of $80 \%$ whey protein concentrate. J. Dairy Sci. 95:2848-2862.

Jervis, S. M., and M. A. Drake. 2013. The impact of iron on the bleaching efficacy of hydrogen peroxide in liquid whey systems. J. Food Sci. 78:R129-R137.

Li, X. E., R. E. Campbell, A. J. Fox, P. D. Gerard, and M. A. Drake. 2012. Influence of storage, heat treatment, and solids composition on the bleaching of whey with hydrogen peroxide. J. Food Sci. 77:C798-C804.

Listiyani, M. A. D., R. E. Campbell, R. E. Miracle, D. M. Barbano, P. D. Gerard, and M. A. Drake. 2012. Effect of temperature and bleaching agent on bleaching of liquid cheddar whey. J. Dairy Sci. 95:36-49.

Listiyani, M. A. D., R. E. Campbell, R. E. Miracle, L. O. Dean, and M. A. Drake. 2011. Influence of bleaching on flavor of $34 \%$ whey 
protein concentrate and residual benzoic acid concentration in dried whey proteins. J. Dairy Sci. 94:4347-4359.

Mavropoulou, I. P., and F. V. Kosikowski. 1972. Composition, solubility and stability of whey powders. J. Dairy Sci. 56:1128-1134.

Meilgaard, M. M., G. V. Civille, and B. T. Carr. 2007. Descriptive analysis techniques. Pages 189-254 in Sensory Evaluation Techniques. 4th ed. CRC Press, Boca Raton, FL.

Moriguchi, I., S. Wada, and H. Sano. 1968. Binding of 2-(4'-hydroxyphenylaxo) benzoic acid to bovine serum albumin. Chem. Pharm. Bull. 16:592-596.

Seifu, E. E. M. B., and E. F. Donkin. 2005. Significance of the lactoperoxidase system in the dairy industry and its potential applications: A review. Trends Food Sci. Technol. 16:137-154.

Sithole, R., M. R. McDaniel, and L. Meunier Goddick. 2005. Rate of Maillard browning in sweet whey powder. J. Dairy Sci. 88:16361645 .
Smith, T. J., E. L. Xi, and M. A. Drake. 2014. Norbixin and bixin partitioning in cheddar cheese and whey. J. Dairy Sci. 97:3321-3327.

US Food and Drug Administration. 2009. 21 CFR 184.1366: Hydrogen peroxide. Accessed Mar. 26, 2014. http://www.accessdata.fda.gov/ scripts/cdrh/cfdocs/cfcfr/CFRSearch.cfm?fr $=184.1366$.

Wedzicha, B. L., and S. Ahmed. 1993. Distribution of benzoic acid in an emulsion. Food Chem. 50:9-11.

Whitson, M. E., R. E. Miracle, and M. A. Drake. 2010. Sensory characterization of chemical components responsible for cardboard flavor in whey protein. J. Sens. Stud. 25:616-636.

Wright, J. E., M. E. Carunchia Whetstine, R. E. Miracle, and M. A. Drake. 2009. Characterization of a cabbage off flavor in whey protein isolate. J. Food Sci. 71:C86-C90. 